\section{Psicologia Escolar \\ e Educacional}

PAPER

DOI: http://dx.doi.org/10.1590/2175-35392021225567

Elocation - e225567

\title{
EFFECTS OF AN ELECTRONIC GAME ON EARLY LITERACY SKILLS
}

\author{
Laura V. Sánchez-Vincitore ${ }^{1} \mathbb{D}$; Analía Henríquez Cross ${ }^{1} \mathbb{D}$
}

\begin{abstract}
The attainment of the alphabetic principle is one of the earliest signs of successful literacy acquisition. Public school students from the Dominican Republic have low literacy skills, partly because of not being systematically exposed to the alphabetic principle while learning to read. This paper presents the results of an intervention to teach the alphabetic principle using a tablet-based game. Nineteen kindergarten students were randomly assigned to a control and an experimental group during the last month of the 2017 school year. Students from the experimental group played with the game for ten sessions of 20 minutes each. Students from the experimental group outperformed the control group in syllable recognition after the intervention. The intervention did not influence other reading skills. Automatic syllable identification has been shown to boost early literacy acquisition, although it is not sufficient for students to become fluent readers.
\end{abstract}

Keywords: Literacy; educational games; software; computer games

\section{Efectos de un juego electrónico en las habilidades iniciales de alfabetización}

\section{RESUMEN}

El conocimiento del principio alfabético es una de las primeras señales que apunta a que los alumnos se alfabetizaron con éxito. Los alumnos de escuelas públicas de la República Dominicana tienen bajos niveles de alfabetización, porque, en parte, no son expuestos sistemáticamente al principio alfabético en el proceso de aprender a leer. En este texto se presentan los resultados de una intervención para enseñar el principio alfabético usando un juego para tabletas. Durante el último mes del año escolar de 2017, diecinueve alumnos de pre-primario fueron aleatoriamente asignados a uno de dos grupos: un grupo control y otro experimental. Los alumnos del grupo experimental jugaron con el juego por diez sesiones de 20 minutos cada una. Los alumnos del grupo experimental superaron al grupo de control en el reconocimiento de sílabas tras la intervención. Esta intervención no influyó en otras habilidades de lectura. Se conoce que la identificación automática de sílabas promueve el aprendizaje de la lectura, pero no es suficiente para que los alumnos alcancen la fluidez lectora.

Palabras clave: alfabetización; juegos educativos; software; juegos de computador

\section{Efeitos de um jogo eletrônico nas habilidades iniciais de alfabetização}

\section{RESUMO}

Um dos primeiros sinais da alfabetização bem-sucedida é a assimilação do princípio alfabético. Os alunos de escolas públicas da República Dominicana têm baixo nível de alfabetização, em parte por não serem sistematicamente expostos ao princípio alfabético quando estão aprendendo a ler. Este artigo apresenta os resultados de uma intervenção para o ensino do princípio alfabético por meio de um jogo para tablet. Dezenove alunos da educação infantil foram aleatoriamente designados para um grupo controle e um grupo experimental durante o último mês do ano letivo de 2017. Os alunos do grupo experimental brincaram com o jogo por dez sessões de 20 minutos cada. Os alunos do grupo experimental superaram o grupo de controle no reconhecimento de sílabas após a intervenção. A intervenção não influenciou outras habilidades de leitura. Foi demonstrado que a identificação automática de sílabas aumenta a alfabetização precoce, embora não seja suficiente para que os alunos se tornem leitores fluentes.

Palavras-chave: alfabetização; jogos educativos; software; jogos de computador.

${ }^{1}$ Universidad Iberoamericana - Santo Domingo - República Dominicana; I.sanchez1@prof.unibe.edu.do; a.henriquez@unibedom. onmicrosoft.com 


\section{INTRODUCTION}

The alphabetic principle refers to the reader's knowledge that visually presented letters and letter combinations represent specific sounds. In other words, that graphemes represent phonemes (Adams, 1990; Byrne, 2014). According to Apel, Henbest, and Masterson (2019), the alphabetic principle is the act of phonological recoding that binds two types of knowledge together: (a) the knowledge about the sound structure of the language (or phonological awareness) and (b) the knowledge about visually presented letters. After multiple trials of translation from grapheme to phoneme and vice-versa, the reader reaches an early stage of unitization, that is, the ability to recognize parts of the word as a whole, which in fact, is necessary to attain reading automaticity (Ham et al., 2015). Reading automaticity develops when decoding words becomes effortless, allowing the reader to allocate cognitive resources towards more sophisticated reading skills such as comprehension (LaBerge \& Samuels, 1974; Samuels, 2004).

There are multiple ways to acquire the alphabetic principle. Two of the most renowned ways are by either exposing the child to whole words or text while guiding them to discover the patterns between graphemes and phonemes intuitively, and the other is by teaching the alphabetic principle explicitly through systematic instruction (Byrne, 2013). These practices are not mutually exclusive; however, evidence from education, cognitive psychology, and neuroscience recommends prioritizing the latter in early literacy acquisition (Ehri et al., 2001; Taylor et al., 2017). In other words, the teaching of the alphabetic principle should be progressive (from simpler to harder), systematic, and constant.

Mobile technology -initially designed for communication and entertainment-has now become a crucial element of growth in multiple contexts, including the education sector (Shuler et al., 2013)tableta o smart phone, netbooks, since it can support pedagogy, distribute content, assist in training and evaluation (Traxler \& Vosloo, 2014). Mobile devices present a potential benefit for this purpose for the following reasons: Regarding access, these devices are becoming inexpensive, and they are widely used. Concerning the possibility of content and training distribution, the ability to provide immediate feedback, and to time stimulus presentation are the basis of systematic instruction, including the instruction of the alphabetic principle. Large classrooms make it impossible for teachers to provide immediate feedback for each student, limiting the ability to present stimuli fast enough to boost the rapid recognition of letter combinations, which could be overcome by technology.
The use of technology for reading instruction has shown to be an effective strategy to boost early literacy skills (Blok et al., 2002). For example, the Finnish mobile game by the name of GraphoGame teaches the alphabetic principle using multiple-choice platforms to practice grapheme-phoneme combinations, decoding, and word reading. GraphoGame trials have been successful in various sociodemographic contexts and with the intervention of different duration times (Borleffs et al., 2017; Kamykowska et al., 2013; Kyle et al., 2013; Ngorosho, 2018; Ojanen et al., 2015; Patel et al., 2018; Richardson \& Lyytinen, 2014; Ronimus \& Richardson, 2014; Röthlisberger et al., 2015)a country with a population of more than 1.3 billion individuals, houses the world's second largest educational system. Despite this, hundreds of millions of individuals in India are still illiterate. As English medium education sweeps the country, many are forced to learn in a language which is foreign to them. Those living in poverty further struggle to learn English as it tends to be a language which they have no prior exposure to and no support at home for. Low-quality schools and poor instructional methods further exacerbate the problem. Without access to quality education, these individuals continue to struggle and are ultimately never given the chance to break the cycle of poverty. The aim of this study was to determine whether GraphoLearn, a computer-assisted reading tool, could be used to support the English reading skills of struggling readers in India. Participants were 7-year-old, grade 3 students ( $\mathrm{N}=30$.

Our research team designed a mobile app to be used by school-aged children who are learning to read and write in their native language, given the evidence of successful literacy interventions through mobile technology and the investment in technology for education in the Dominican Republic Spanish. We based the software's content on the recommendations by Defior, Justicia, and Martos (1998) and Abadzi, Marinelli, Martelli, Praphamontripong, and Zoccolotti (2013) towards best practice in Spanish early literacy teaching that consist of: (1) combination of phonological awareness with explicit instruction of the alphabetic principle; (2) sequential presentation of the alphabetic principle; (3) constant repetition, so students overlearn letter combinations; (4) provision of immediate feedback; (5) slow pace rhythm; and (6) systematic revision of previous knowledge.

This study aimed to determine if students who received the tablet-based intervention in the alphabetic principle show more gains in literacy skills -at least in syllable reading- than students who do not receive the intervention.

\section{METHOD}

This study follows an experimental design with 
random assignment to experimental and control groups, with pre-intervention and post-intervention evaluations. We used block randomization to ensure that groups resulted in equal sample sizes.

\section{Participants}

Twenty-two kindergarten students (mean age $=5.37$, $\mathrm{SD}=0.6)$ participated in this study. They go to a public school in Santo Domingo in a neighborhood of low socioeconomic positions. One participant was excluded from the study since she had received intensive literacy training in an off-campus afterschool activity. Two students were not available for post-test and therefore were excluded from the analysis. Therefore, 19 students were randomly assigned to either the experimental group or the control group.

\section{Ethical Considerations}

The Universidad Iberoamericana's Ethics Committee approved this study. Since this project is part of a broader international cooperation project, the Ministry of Education included all testing associated with it to its regular assessment process, and parents gave consent to test their children. Evaluators obtained a verbal assent from each child before every evaluation and every intervention session.

\section{INTERVENTION}

Experimental group. In addition to regular schooling, students from the experimental group received the tablet-based intervention for 3.5 weeks. The intervention consisted of playing the Aventura de las Letras electronic game for ten sessions distributed across the three weeks for 20 minutes each session. Students went in a quiet room in groups of 5 , where they sat on a desk with the tablets and headphones. The students played the game individually. A research assistant stayed in the room during all sessions to ensure active student participation and to avoid distractions. The game was programmed so that participants were exposed at least ten times for each possible grapheme-phoneme combination. Previously seen combinations were presented to participants with current combinations in order for participants to review all combinations.
The Aventura de las Letras is a multiple-choice game that teaches the alphabetic principle by presenting Spanish syllables in sequential order. The sequence was determined by letter and syllable frequency in Spanish. See Table 1 for the grapheme-phoneme presentation.

The game consisted of matching an auditory stimulus (phoneme) with the corresponding visual stimuli (grapheme). Participants chose one from three possible graphemes, and only one grapheme was the correct response. After every trial, participants received immediate feedback from the game. Successful trials made a victory sound effect, along with a visual "energy crystal." Every successful trial filled an "energy bar." Upon completion of the energy bar, the activity finished. Unsuccessful trials made a neutral sound effect, indicating an incorrect response. Unsuccessful trials did not fill the energy bar. When participants made a mistake, the energy crystal appeared on top of the correct response, so that participants had the opportunity to learn from their mistakes. Upon completing each activity, student performance was rated from zero to three stars. Participants were encouraged to finish all the activities with three stars. The software was designed using the Cocos $2 \mathrm{~d}$-js, which allowed running the game on multiple platforms, including Android, Windows, iOS, and Linux. Illustrations from the software were designed explicitly with culturally relevant elements (Figure 1 ).

\section{Instruments}

Sociodemographic questionnaire. This was a short questionnaire to determine sex, age, handedness, languages spoken at home, the number of books at home, and home literacy habits.

Literacy sub-skills battery. We adapted the Project USAID-Read reading assessment battery (Mencía-Ripley et al., 2016) to test specific literacy sub-skills. The original battery was created for project USAID-Read, an initiative to improve literacy skills in Dominican children. The test showed adequate psychometric properties and was developed with international standards for early grade reading assessment. This adaptation showed appropriate internal consistency, as evidenced by acceptable Cronbach's alphas ( $\alpha$ from 0.64 to 0.99 ).

Table 1. Grapheme Presentation Order According to The Frequency in Spanish.

\begin{tabular}{|c|c|c|}
\hline & Graphemes & Syllable type \\
\hline Stage 1 & amenosilu & $\mathrm{V}, \mathrm{CV}$ \\
\hline Stage 2 & $y(i) f p t b d$ & $\mathrm{~V}, \mathrm{CV}, \mathrm{VC}$ \\
\hline Stage 3 & $c(k) q \vee \| l y c h b l f l p l c l$ & $\mathrm{~V}, \mathrm{CV}, \mathrm{VC}, \mathrm{CCV}$ \\
\hline Stage 4 & $g(g)$ gu gü gl r rr & $\mathrm{V}, \mathrm{CV}, \mathrm{VC}, \mathrm{CCV}$ \\
\hline Stage 5 & j $g(j) c(s) z b r c r d r f r$ & $\mathrm{~V}, \mathrm{CV}, \mathrm{VC}, \mathrm{CCV}$ \\
\hline Stage 6 & gr prtr $\operatorname{n} \mathrm{cc} \times \mathrm{k} \mathrm{w}$ & $\mathrm{V}, \mathrm{CV}, \mathrm{VC}, \mathrm{CCV}$ \\
\hline
\end{tabular}




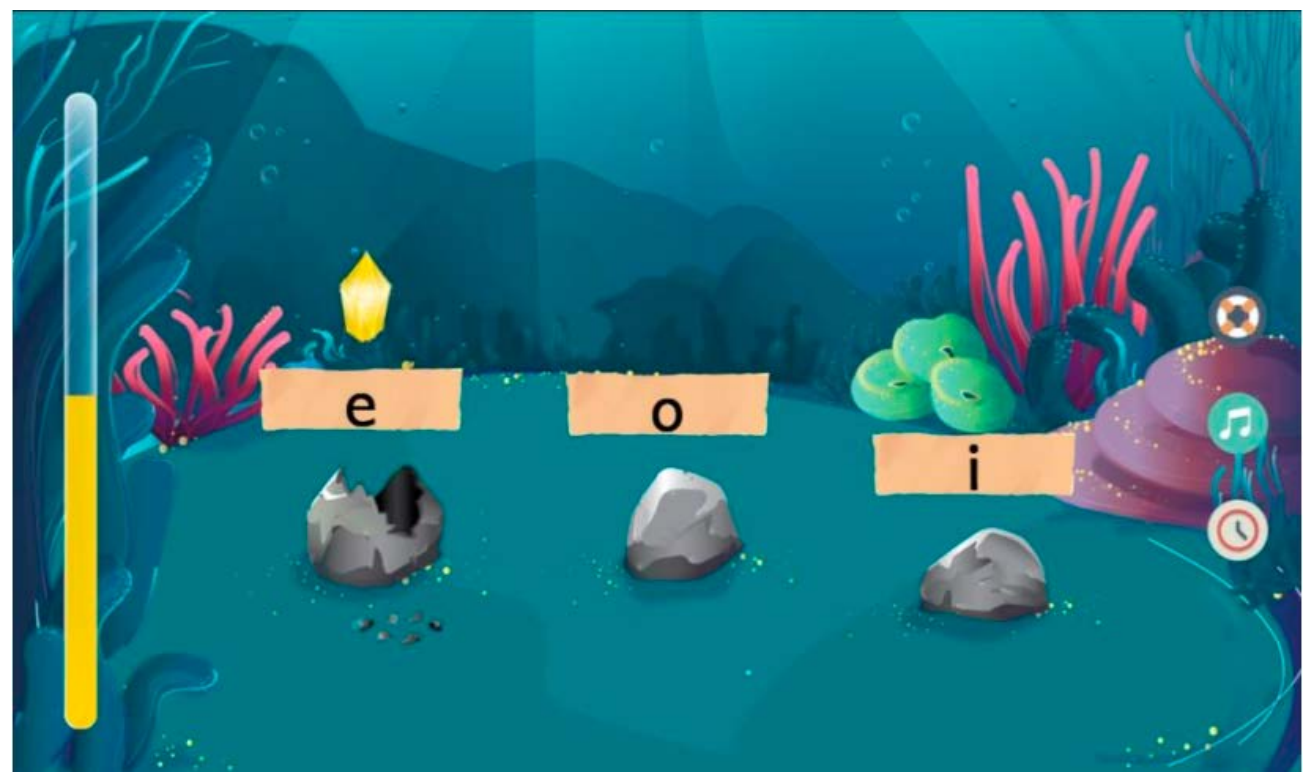

Figure 1. La Aventura de las Letras Game Layout.

Control group. Students from this group received regular schooling.

Phonological awareness - initial sound. This test measures the ability to detect the initial sound of a word. It is part of the Project USAID-Read Reading Assessment Battery (Mencía-Ripley et al., 2016), which was developed with international standards for early grade reading assessment (EGRA).

Phonological awareness - sound discrimination. This test measures the ability to discriminate the initial sound of 3 words presented sequentially by asking the student to detect a target word that starts with a different sound compared to the other two. It is part of the project USAID-Read Assessment Battery. The test contains ten trials of word triads, and target words are presented in different locations (first, second, or third word).

Letter knowledge. This is a speed test that assesses how fast and how well students know the letters. Students are asked to either say the name or sound of individual letters presented on a piece of paper in one minute. This test was also part of the project USAIDRead Reading Assessment Battery.

Syllable per minute. This test was created specifically for this intervention. It is a speed test that assesses syllable reading presented on a piece of paper in one minute. The syllables are presented in a sequential order to follow the exact sequence used by the tablet-based intervention.

Words per minute. This is a speed test that assesses high-frequency word reading presented on a piece of paper in one minute. This test was also part of the project Read Reading Assessment Battery.

Spelling. This test was created specifically for this intervention. Students are asked to write a list of 5 words individually. The words are high frequency and contain only first stage syllables.

\section{PROCEDURE}

We invited a school enrolled in project USAID-Read. For this purpose, the research team met with the principal, vice-principal, and kindergarten teacher who agreed to participate. Three offices were designated for testing and intervention.

For the pre-test, a group of 3 research assistants visited the school. Upon arrival, they invited each kindergarten student to participate in the study. After obtaining their verbal assent, each research assistant brought the participant to the designated office. All students were willing to participate. The pre-test was conducted individually. Once the child was in the office, the researcher started the interview with the sociodemographic questionnaire, followed by the reading assessment. When the evaluation concluded, the researcher took the child back to the classroom and began the same process with a different child.

For the intervention, a research assistant brought five children from the experimental group at a time to the designated office where they spent twenty minutes playing with the Aventura de las Letras game.

The post-test followed the same procedure as the pre-test, with the difference that the research assistants were blind to group assignment, preventing evaluation bias.

\section{Data Collection and Analysis}

Data collection was conducted using Tangerine, a tablet-based data acquisition software developed by 
RTI International. It is an electronic system designed to assess early reading skills. We used 7 inches ACER B1-770 Android tablets version 5.0.1. Upon completion of each evaluation, we synchronized the data to a dedicated server hosted by the Universidad Iberoamericana. Data processing was conducted in Microsoft Excel, and data analysis was performed in JASP (JASP Team, 2018).

To answer the research question related to the gains in literacy skills for both groups, we first computed gain scores for each participant. The following formula contains the calculation:

$\mathrm{d}=\mathrm{y}-\mathrm{x}$

Where $d$ is the difference (gain) score, $y$ is the posttest score, and $x$ is the pre-test score. A one-tailed independent sample t-test was conducted to compare gain score means between groups.

\section{RESULTS}

\section{Overall Reading Sub-Skills Scores Before Intervention}

Students who participated in this study $(n=19)$ had an average accuracy rate of $14 \%$ and $24.22 \%$ on phonological awareness measurements. Students recognized on average 4.74 letters per minute (SD = $4.50), 2.42$ syllables per minute $(S D=3.73)$, and 0.32 words per minute $(S D=0.75)$.

After randomly assigning participants to either the control and experimental group, we ran an independent sample t-test on each literacy sub-skill to ensure both groups had similar performance. As shown in Table 2 , there were no statistically significant differences between groups on the pre-test.

To obtain gain scores for each participant, we subtracted pre-test scores from post-test scores, and then we ran a one-tailed independent sample t-test to determine if the experimental group had more substantial gains than the control group. This was conducted on each literacy sub-skill test.

Students who received the tablet-based alphabetic principle intervention showed more gains on syllable reading than students who did not receive the intervention $\left(t_{17}=-1.807, p=0.044\right)$. The difference between groups had large effect sizes $\left(d^{\prime}=-0.830\right)$. There were no statistically significant differences between groups on gains in other reading sub-skills. Table 3 contains inferential statistics that compare both groups on each literacy sub-skill gain, and Figure 2 contains a visual representation of these comparisons.

\section{DISCUSSION}

This study found that kindergarten students that received the tablet-based alphabetic principle intervention had more gains on syllable reading than students who did not receive the intervention at the end of the school year. The intervention targeted graphemephoneme conversions at the syllable level, and therefore, a significant effect was expected on syllable reading. Other literacy sub-skills - such as phonological

Table 2. T-Test Results Comparing Control and Experimental Group on Literacy Sub-Skills Before the Intervention.

\begin{tabular}{lcccc}
\hline & $\mathbf{t}$ & $\mathbf{d f}$ & $\mathbf{p}$ & Cohen's d \\
\hline Phonological awareness - initial sound & 1.005 & 17 & 0.329 & 0.462 \\
Phonological awareness - sound discrimination & 1.045 & 17 & 0.310 & 0.480 \\
Letter knowledge & -0.984 & 17 & 0.339 & -0.452 \\
Syllable per minute & -0.957 & 17 & 0.352 & -0.440 \\
Words per minute & -0.506 & 17 & 0.620 & -0.232 \\
Spelling & 0.155 & 17 & 0.879 & 0.071 \\
\hline
\end{tabular}

Gain Scores Comparisons Between Control and Experimental Groups.

Table 3. T-Test Results Comparing Control and Experimental Groups on Literacy Sub-Skill Gain Scores.

\begin{tabular}{lcccc}
\hline & t & df & p & Cohen's d \\
\hline Phonological awareness - initial sound & -1.088 & 17 & 0.146 & -0.500 \\
Phonological awareness - sound discrimination & -0.167 & 17 & 0.435 & -0.077 \\
Letter knowledge $_{\text {Syllable per minute }}$ & 1.540 & 17 & 0.929 & 0.708 \\
Words per minute $_{\text {Spelling }}$ & -1.807 & 17 & 0.044 & -0.830 \\
\hline
\end{tabular}

Note. The alternative hypothesis specifies that group Control is less than group Experimental.

Corrected for unequal variance. 


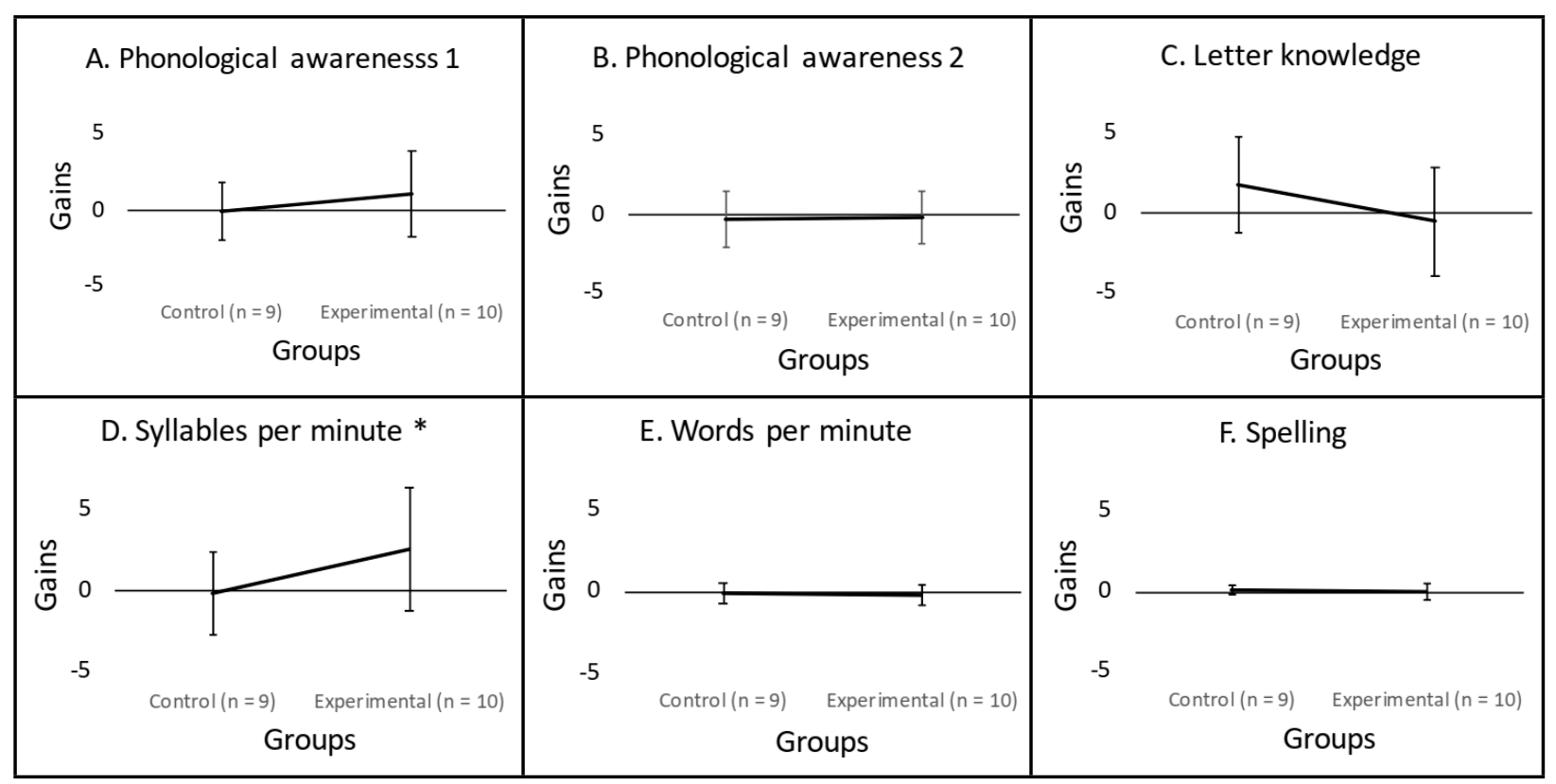

Figure 2. Average Gain Scores on Reading Sub-Skills for Control and Experimental Groups.

Note. Phonological awareness 1 = initial sound; Phonological awareness 2 = sound discrimination. Gain scores were calculated by subtracting pre-test scores from post-test scores on each literacy sub-skill for each group participant. Error bars are standard deviations. ${ }^{*} \mathrm{p}<.05$ for an independent sample t-test

awareness, letter knowledge, word reading, and spelling did not change after the intervention. Another electronic alphabetic principle game found that systematic phonics instruction in school in highly transparent languages might be sufficient to ensure that students obtain the alphabetic principle, and therefore might not need this electronic resource to acquire it (Kamykowska et al., 2013). Although Spanish is considered a shallow orthography, students in the Dominican Republic do not receive systematic phonics instruction (Minerd, 2014). Therefore, a game like La Aventura de las Letras might be beneficial during early literacy acquisition.

The short duration of the intervention might explain the non-transferability of significant effects on other literacy sub-skills. Since the intervention was conducted during the last month of the academic year, we were allowed to work with the children for only 3.5 weeks distributed in 10 sessions of 20 minutes. Therefore, it is understandable that, in such a short period, the skill that would show significant changes over time is the skill that was explicitly targeted in the intervention, that is, syllable reading. Other alphabetic principle electronic games have found similar outcomes in obtaining significant differences in specifically targeted skills, but such an effect does not transfer to other skills. For example, first-grade Zambian students playing GraphoGame showed increased spelling scores after 3 hours of exposure, distributed in 3 and 5 consecutive days (Jere-Folotiya et al., 2014).
The research assistant in charge of the intervention noted that after children played for a couple of sessions, student involvement decreased, and it became a little more challenging to maintain all the students focused on the game. Although this was anecdotal evidence, other studies have reported reduced engagement after playing these games for an extended period (Ronimus et al., 2014)a web-based game training letter-sound connections, at home under the supervision of parents. Data regarding the children's gaming and engagement were stored on the GraphoGame online server. A 2 ?? 2 factorial design was used to investigate the effects of the level of challenge (high challenge vs. high success. This needs further exploration since literacy is acquired through constant and repetitive practice. Also, this supports the need to have multiple resources to tackle the instructional need for repetition. For a student to practice a determined set of grapheme-phoneme conversions, the electronic game should not be the only resource used. Other materials should be presented to target the specific combination, ensuring practice and engagement.

The study has limitations. Our sample of kindergarten students was small. In terms of random assignment, small sample sizes do not always guarantee that both groups are equivalent in terms of scores before the intervention. Also, low sample sizes have low power; therefore, any difference between groups must have large effect sizes to reach significance. This could explain 
the fact that we found significant results on syllable reading only, since the intervention on the alphabetic principle explicitly targeted this skill, and therefore its impact is expected to have a large effect size. Other potential differences could have been undetected due to small effect sizes.

Further studies should consider larger sample sizes and the game's use during a whole academic year, preferably first grade, since children are expected to know the alphabetic principle by the end of this grade. La Aventura de las Letras is a game that presents the grapheme-phoneme combination that forms syllables in sequential order, from more frequent/easier combinations to less frequent/harder combinations. For a study to explore its full effect, it would be necessary to allow the students to complete the whole game, for them to be exposed to all graphemephoneme conversions, and to be allowed to practice these conversions for more extended periods. Finding significant differences at the syllable level after such a short intervention is a positive result, but it certainly needs further exploration.

La Aventura de las Letras does not intend to be a teacher substitute but a supplementary practice activity that children can work on during literacy acquisition. Since it provides systematic exposure to graphemes and grapheme combinations of increasing difficulty, it could guide teachers through conducting phonics instruction. Besides, this game provides students with immediate feedback after every single trial, which is impossible to achieve in classroom settings, where there are usually more than 25 students per teacher. It is important to note that although the alphabetic principle is crucial for learning to read, this is not the only skill necessary for children to become fluent readers. The game is part of a more comprehensive literacy training program that includes, among other strategies, a collection of decodable books for first and second-grade students. Decodable books are practice books designed with the same grapheme-phoneme frequency from the Aventura de las Letras game, allowing students to read real content using the game's stimuli (Sánchez-Vincitore, 2018).

\section{REFERENCES}

Abadzi, H.; Marinelli, C. V.; Martelli, M.; Praphamontripong, P.; Zoccolotti, P. (2013). Visual and linguistic factors in literacy acquisition: Instructional implications for beginning readers in low-income countries (working paper series on learning, no. 2). Global Partnership for Education (GPE): World Bank, Washington, DC. Recovered from https://openknowledge. worldbank.org/handle/10986/16244

Adams, M. J. (1990). Begining to read: Thinking and learning about print. Cambridge: Massachusetts Institute of Technology.

Apel, K.; Henbest, V. S.; Masterson, J. (2019). Orthographic knowledge: Clarifications, challenges, and future directions. Reading and Writing, 32(4), 873-889. https://doi. org/10.1007/s11145-018-9895-9

Blok, H.; Oostdam, R.; Otter, M. E.; Overmaat, M. (2002). Computer-assisted instruction in support of beginning reading instruction: A review. Review of Educational Research, 72(1), 101-130. https://doi. org/10.3102/00346543072001101

Borleffs, E.; Glatz, T. K.; Daulay, D. A.; Richardson, U.; Zwarts, F.; Maassen, B. A. M. (2017). GraphoGame SI: The development of a technology-enhanced literacy learning tool for Standard Indonesian. European Journal of Psychology of Education, (7), 1-19. https://doi. org/10.1007/s10212-017-0354-9

Byrne, B. (2013). Experimental analyisis of the child's discovery of the alphabetic principle. In: Rieben, L.; Perfetti, C. A. (Eds.), Learning to read: Basic research and its implications (pp. 75-84). Abingdon, UK: Routledge.

Byrne, B. (2014). The foundation of literacy: The child's acquisition of the alphabetic principle. East Sussex, UK: Psychology Press.

Defior, S.; Justicia, F.; Martos, F. (1998). Desarrollo del reconocimiento de palabras en lectores normales y retrasados en función de diferentes variables lingüísticas. Infancia y Aprendizaje, 83, 59-74. https:// doi.org/10.1174/021037098760403479

Ehri, L. C.; Nunes, S. R.; Stahl, S. a.; Willows, D. M. (2001). Systematic phonics instruction helps students learn to read: Evidence from the national reading panel's meta-analysis. Reading Research Quarterly, 36(3), 250-287. https://doi. org/10.3102/00346543071003393

Ham, B.; Stoolmiller, M.; Chard, D. J. (2015). Measuring the dimensions of alphabetic principle on the reading development of first graders: the role of automaticity and unitization. Journal of Learning Disabilities, 41(2), 143-157. https://doi.org/10.1177/0022219407313585

Jere-Folotiya, J.; Chansa-Kabali, T.; Munachaka, J. C.; Sampa, F.; Yalukanda, C.; Westerholm, J.; ... Lyytinen, H. (2014). The effect of using a mobile literacy game to improve literacy levels of grade one students in Zambian schools. Educational Technology Research and Development, 62(4), 417-436. https://doi.org/10.1007/s11423-014-9342-9

Kamykowska, J.; Haman, E.; Latvala, J. M.; Richardson, U.; Lyytinen, H. (2013). Developmental changes of early reading skills in six-year-old Polish children and GraphoGame as a computer-based intervention to support them. L1 Educational Studies in Language and Literature, 13(1-18).

Kyle, F.; Kujala, J.; Richardson, U.; Lyytinen, H.; Goswami, U. (2013). Assessing the effectiveness of two theoretically motivated computer-assisted reading interventions in the United Kingdom: GG Rime and GG Phoneme. Reading Research Quarterly, 48(1), 61-76. https://doi.org/10.1002/ rrq.038

LaBerge, D.; Samuels, S. J. (1974). Toward a theory of automatic information processing in reading. Cognitive 
Psychology, 6(2), 293-323. https://doi.org/10.1016/00100285(74)90015-2

Mencía-Ripley, A.; Sánchez-Vincitore, L. V.; Garrido, L. E.; Aguasvivas-Manzano, J. A. (2016). USAID-Leer Baseline Report.

MINERD. (2014). Diseño curricular: Nivel primario. Santo Domingo, República Dominicana. Recovered from http:// www.ibe.unesco.org/fileadmin/user_upload/archive/ curricula/dominicanrepublic/dr_upr_2014_spa.pdf

Ngorosho, D. (2018). Enhancing the acquisition of basic reading skills in Kiswahili using GraphoGame. Papers in Education and Development, 35. Recovered from https:// journals.udsm.ac.tz/index.php/ped/article/view/1488

Ojanen, E.; Ronimus, M.; Ahonen, T.; Chansa-Kabali, T.; February, P.; Jere-Folotiya, J.; ... Lyytinen, H. (2015). GraphoGame - a catalyst for multi-level promotion of literacy in diverse contexts. Frontiers in Psychology, 6, 1-13. https://doi.org/10.3389/fpsyg.2015.00671

Patel, P.; Torppa, M.; Aro, M.; Richardson, U.; Lyytinen, H. (2018). GraphoLearn India: The effectiveness of a computer-assisted reading intervention in supporting struggling readers of English. Frontiers in Psychology, 9, 1-14. https://doi.org/10.3389/fpsyg.2018.01045

Richardson, U.; Lyytinen, H. (2014). The Graphogame Method: the Theoretical and Methodological Background of the Technology-Enhanced Learning Environment for Learning To Read. Human Technology: An Interdisciplinary Journal on Humans in ICT Environnements, 10(May), 39-60. https:// doi.org/http://dx.doi.org/10.17011/ht/urn.201405281859

Ronimus, M.; Kujala, J.; Tolvanen, A.; Lyytinen, H. (2014). Children's engagement during digital game-based learning of reading: The effects of time, rewards, and challenge. Computers and Education, 71, 237-246. https://doi. org/10.1016/j.compedu.2013.10.008

Ronimus, M.; Richardson, U. (2014). Entrenamiento de habilidades de lectura tempranas basado en un juego digital: Visión general del método GraphoGame en una ortografía altamente transparente. Estudios de Psicologia, 35(3), 648-661. https://doi.org/10.1080/02109395.2014 .974424

Röthlisberger, M.; Karipidis, I. I.; Pleisch, G.; Dellwo, V.; Richardson, U.; Brem, S. (2015). Swiss GraphoGame: Concept and design presentation of a computerised reading intervention for children with high risk for poor reading outcomes. Proceedings of the Annual Conference of the International Speech Communication Association, INTERSPEECH, 2015-Janua, 1878-1879.

Samuels, S. J. (2004). Toward a theory of automatic information processing in reading, revisited. In: R. B. Ruddell \& N. J. Unrau (Eds.), Theoretical models and processes of reading (Fifth Edit, pp. 1127-1148). Newark, DE: International Reading Association.

Sánchez-Vincitore, L. V. (2018). Creación de una colección de libros decodificables para la práctica lectora inicial en el idioma español. Ciencia y Educación, 2, 63-72.

Shuler, C.; Winters, N.; West, M. (2013). El futuro del aprendizaje móvil: Implicaciones para la planificación y la formulación de políticas. UNESCO: Paris.

Taylor, J. S. H.; Davis, M. H.; Rastle, K. (2017). Comparing and validating methods of reading instruction using behavioural and neural findings in an artificial orthography. Journal of Experimental Psychology: General, 146(6), 826. http:// dx.doi.org/10.1037/xge0000301

Traxler, J.; Vosloo, S. (2014). Introduction: The prospects for mobile learning. Prospects, 44(1), 13-28. https://doi. org/10.1007/s11125-014-9296-z

\section{Acknowledgments}

We want to thank Yolanda Guerrero, RA, for her support in the school; María del Mar Camilo Caram, Rosa Hilda Cueto and Melody Arias for their support in data collection; José Armando Aguasvivas and Denisse Lara for designing the app.

Acknowledgement of financial support: This study was funded by the Fondo Nacional de Investigación y Desarrollo Científico y Tecnológico (FONDOCYT) from the Dominican Ministry of Higher Education (MESCYT) 2015-2C5-056.

Received: June 24, 2019

Approved: July 18, 2020 